\title{
Molecular epidemiology and characterization of human coronavirus in Thailand, 2012-2013
}

\author{
Rapeepun Soonnarong ${ }^{1}$, llada Thongpan², Sunchai Payungporn' ${ }^{1}$, Chanpim Vuthitanachot ${ }^{3}$, \\ Viboonsuk Vuthitanachot ${ }^{3}$, Preeyaporn Vichiwattana ${ }^{2}$, Sompong Vongpunsawad ${ }^{2}$ and Yong Poovorawan ${ }^{2 *}$
}

\begin{abstract}
Background: Coronavirus causes respiratory infections in humans. To determine the prevalence of human coronavirus (HCoV) infection among patients with influenza-like illness, 5833 clinical samples from nasopharyngeal swabs and aspirates collected between January 2012 and December 2013 were examined.

Results: HCoV was found in 46 (0.79 \%) samples. There were 19 (0.32 \%) HCoV-HKU1, 19 (0.32 \%) HCoV-NL63, 5 (0.09\%) HCoV-229E, and 3 (0.05 \%) HCoV-OC43. None of the sample tested positive for MERS-CoV. The majority (54\%) of the HCoV-positive patients were between the ages of 0 and 5 years. $\mathrm{HCoV}$ was detected throughout the 2-year period and generally peaked from May to October, which coincided with the rainy season. Phylogenetic trees based on the alignment of the spike (S) gene sequences suggest an emergence of a new clade for HCoV-229E.

Conclusions: The data in this study provide an insight into the prevalence of the recent circulating HCoVs in the region.
\end{abstract}

Keywords: Human coronavirus (HCoV), Epidemiology, Respiratory tract infection (RTI), Thailand

\section{Background}

Human coronavirus ( $\mathrm{HCoV}$ ) is an enveloped positivestrand RNA virus with $\sim 27-32 \mathrm{~kb}$ genome. Its genome contains five major open reading frames (Orfs) encoding the replicase polyproteins (Orf 1a and Orf 1b), spike (S), envelope (E), membrane (M), and nucleocapsid (N) proteins (Hilgenfeld and Peiris 2013). HCoV belongs to the order Nidovirales, family Coronaviridae and the genus Coronavirus (Lai and Cavanagh 1997). Virions are pleomorphic with diameters between 60 and $220 \mathrm{~nm}$. There are four genera of coronaviruses (Alpha-, Beta-, Gammaand Deltacoronavirus) based on serologic and phylogenetic characterization. Among the five recognized human coronaviruses, HCoV strains 229E and NL63 are alphacoronaviruses, while $\mathrm{HCoV}$ strains OC43, HKU1, and SARS (responsible for the severe acute respiratory

\footnotetext{
*Correspondence: yong.p@chula.ac.th

${ }^{2}$ Center of Excellence in Clinical Virology, Department of Pediatrics, Faculty of Medicine, Chulalongkorn University, Bangkok, Thailand Full list of author information is available at the end of the article
}

syndrome) are betacoronaviruses (Gaunt et al. 2010; Gonzalez et al. 2003; Drosten et al. 2003). In addition, a novel genotype of coronavirus was identified in Saudi Arabia in 2012, later referred to as MERS-CoV (for the Middle East respiratory syndrome coronavirus), which was isolated from the sputum of a 60-year-old man in Saudi Arabia who presented acute pneumonia and renal failure with a fatal outcome (Hilgenfeld and Peiris 2013; Zaki et al. 2012). It was subsequently found to be most closely related to the bat betacoronavirus HKU4 and HKU5 (Gonzalez et al. 2003). Fortunately, the conserved structure and function of the polymerase made it possible to develop a PCR assay based on the polymerase gene region to accurately differentiate new coronaviruses as was done with MERS-CoV and other novel coronaviruses (Rota et al. 2003; Moës et al. 2005).

$\mathrm{HCoVs}$ are recognized as one of the most frequent causes of upper respiratory tract infection in elderly adults leading to acute pneumonia and renal failure (Memish et al. 2013; Gorse et al. 2009). HCoV infection 
is thought to participate in the exacerbations of chronic obstructive pulmonary disease, congestive heart failure, and other chronic diseases necessitating emergency care and long-term hospitalization. In addition to respiratory syncytial virus, parainfluenza virus, adenovirus, and influenza virus, $\mathrm{HCoVs}$ are also known to cause the common cold especially among children (Moës et al. 2005; $\mathrm{Lu}$ et al. 2012). Furthermore, HCoVs are associated with mild to severe upper and lower respiratory tract illness and can cause more serious respiratory diseases in children, the elderly and people with underlying conditions (McIntosh et al. 1974; van Elden et al. 2004).

The study of coronaviruses has sometimes been difficult due to limitations in cell culture and serology. Thus, epidemiological and viral prevalence data are valuable in investigating the emergence of $\mathrm{HCoV}$ infection. Using reverse-transcription polymerase chain reaction (RTPCR) and phylogenetic analysis, we characterized HCoVs identified in Thai patients with respiratory tract infection between 2012 and 2013.

\section{Methods \\ Clinical samples}

This study was approved by the Faculty of Medicine of Chulalongkorn University (IRB 388/56). A total of 5833 clinical samples from patients with influenza-like illness were obtained between January 2012 and December 2013 for routine testing of respiratory viruses as part of an epidemiological surveillance (Auksornkitti et al. 2014; Prachayangprecha et al. 2013; Sriwanna et al. 2013). From these, 5196 nasopharyngeal swabs (NPS) were collected from patients with upper respiratory tract infections who sought treatment at the Bangpakok 9 International Hospital and Chum Phae Hospital (Khon Kaen, Thailand). Additionally, 637 nasopharyngeal aspirates (NPA) were collected from patients with lower respiratory tract infections who were admitted to King Chulalongkorn Memorial Hospital and Chon Buri Hospital. All samples were stored in the viral transport medium (prepared according to The World Health Organization guideline). Patient identifiers were removed and all samples were anonymous, although data on demographics, symptoms, history of illness, results of clinical examination and laboratory investigations were retained for analysis.

\section{Coronavirus detection}

Viral DNA/RNA was extracted using HiYield Viral Nucleic Acid Extraction Kit (RBC Bioscience, Taipei, Taiwan, ROC). Complementary DNA was synthesized with random hexameric primers and ImProm-II (Promega, Madison, WI, USA) according to the manufacturer's instructions. $\mathrm{HCoV}$ was identified using the semi-nested RT-PCR to amplify the RNA-dependent RNA polymerase
$(R d R p)$ gene of $\mathrm{HCoV}$ and the $N$ gene of MERS-CoV as previously described (Corman et al. 2012; Kon et al. 2012). For controls, a panel of viral nucleic acid extracted from samples previously tested positive for influenza A virus [subtype H1N1 (pandemic 2009), H3N2], influenza $B$ virus, respiratory syncytial virus (RSV), human parainfluenza virus (HPIV) and human adenovirus was used to determine the specificity of the $\mathrm{HCoV}$ semi-nested RTPCR. PCR was performed using the PerfectTaq ${ }^{\mathrm{TM}}$ Plus Master Mix kit (5 PRIME, Hamburg, Germany) and primers (Table 1) in $25 \mu \mathrm{L}$ reaction volume under the following conditions: initial denaturation at $94{ }^{\circ} \mathrm{C}$ for $3 \mathrm{~min}$, 40 cycles of $94{ }^{\circ} \mathrm{C}$ for $30 \mathrm{~s}, 55-58{ }^{\circ} \mathrm{C}$ for $30 \mathrm{~s}, 72{ }^{\circ} \mathrm{C}$ for $40 \mathrm{~s}$, and a final extension at $72{ }^{\circ} \mathrm{C}$ for $7 \mathrm{~min}$. Expected amplicons for $\mathrm{RdRp}$ and $\mathrm{N}$ were $\sim 450$ and $\sim 260 \mathrm{bp}$, respectively. All the specimens were positive for GAPDH, which served as an internal control.

To identify the types of HCoVs (HCoV-229E, HCoVNL63, HCoV-OC43, and HCoV-HKU1), the $S$ gene was genotyped using nested RT-PCR. Amplification condition was the same as above except that the annealing temperature was $50^{\circ} \mathrm{C}$. Amplicons were agarose gel-purified using the Expin Gel SV kit (GeneAll, Seoul, Korea) and DNA sequencing was performed by First BASE Laboratories (Seri Kembangan, Selangor, Malaysia).

\section{Sensitivity of semi-nested RT-PCR for coronavirus detection}

PCR products from the amplification of $\mathrm{HCoV}-229 \mathrm{E}$, HCoV-NL63, HCoV-OC43, HCoV-HKU1 and MERS$\mathrm{CoV}$ were cloned into pGEM-T Easy Vector System (Promega, CA, USA) according to the manufacturer's instructions. RNA transcripts from these five coronaviruses were used as standards to validate assay sensitivity. The sensitivity of the semi-nested RT-PCR assay was established for each coronavirus by testing transcripts of known concentrations from serial dilution.

\section{Sequence and phylogenetic analysis}

Nucleotide sequences of the $R d R p$ and $S$ genes were edited using Chromas Lite (version 2.1.1) and compared to the $\mathrm{HCoV}$ reference strains available in GenBank using the Basic Local Alignment Search Tool (BLAST) program (www.ncbi.nlm.nih.gov/Blast.cig). Multiple alignments of the nucleotide sequences utilized Clustal $\mathrm{W}$ in BioEdit (version 7.0.9). Phylogenetic trees were constructed using the neighbor-joining method and the Kimura two-parameter distance model (MEGA version 6.06) and evaluated by 1000 bootstrap pseudo-replicates.

\section{Nucleotide sequences}

The nucleotide sequences of the $R d R p$ gene (accession numbers KJ866056-KJ866101) and the $S$ gene (accession 
Table 1 Sequences of primers used to identify HCoVs in this study

\begin{tabular}{|c|c|c|c|c|}
\hline Gene & Primer & Genotype & Sequence $\left(5^{\prime}-3^{\prime}\right)^{a}$ & PCR application \\
\hline \multirow[t]{3}{*}{ RdRp } & 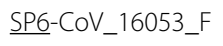 & & ATTTAGGTGACACTATAGGGTTGGGAY TAYCCTAARTGTGA & First and second round \\
\hline & CoV-16594_R & & TAYTATCARAAYAATGTCTTTATGTC & First round \\
\hline & CoV-Pan_16510_R & & TGATGATGGNGTTGTBTGYTATAA & Second round \\
\hline \multirow[t]{16}{*}{$S$} & HCoV-S229E_F1 & $229 \mathrm{E}$ & GTGGGTGCACTACCTAAGAC & First round \\
\hline & HCoV-S229E_R1 & $229 \mathrm{E}$ & CGTGGTTGAACAGCAATTATAGAACC & \\
\hline & HCoV-S229E_F2 & $229 \mathrm{E}$ & GAGTTTGTTATTTCACGCACAGGAC & Second round \\
\hline & HCoV-S229E_R2 & $229 \mathrm{E}$ & CCATCTGCACAAACGCCAAAAC & \\
\hline & HCoV-SHKU1_F1 & HKU1 & TCACCTCTTAATTGGGAACGTA & First round \\
\hline & HCoV-SHKU1_R1 & HKU1 & CATTAGAACAAGTGGTGCCAC & \\
\hline & HCoV-SHKU1_F2 & HKU1 & GATTTGCAGTTGGGCAGTTCTGG & Second round \\
\hline & HCoV-SHKU1_R2 & HKU1 & AAAGGCATCAGGACTACAAA & \\
\hline & HCoV-SNL63_F1 & NL63 & GACACCACAATACCTTTTGG & First round \\
\hline & HCoV-SNL63_R1 & NL63 & CTGGTTGGTTACATGGTGTCAC & \\
\hline & HCoV-SNL63_F2 & NL63 & CATGTTAGCACTTTTGTGGGT & Second round \\
\hline & HCoV-SNL63_R2 & NL63 & CCACCAGCAAGTGACTGGTTTG & \\
\hline & HCoV-SOC43_F1 & OC43 & GTCGGTGCCCTCTCCATTAAATT & First round \\
\hline & HCoV-SOC43_R1 & OC43 & GGCCGCAGAAACACGAC & \\
\hline & HCoV-SOC43_F2 & OC43 & AATATGAGCAGCCTGATGTC & Second round \\
\hline & HCoV-SOC43_R2 & OC43 & CCGAAATAGCAATGCTGGTTC & \\
\hline \multirow[t]{3}{*}{ N } & NSeq-Fwd & MERS & CCTTCGGTACAGTGGAGCCA & First round \\
\hline & NSeq-Fnest & MERS & TGACCCAAAGAATCCCAACTAC & Second round \\
\hline & NSeq-Rev & MERS & GATGGGGTTGCCAAACACAAAC & First and second round \\
\hline
\end{tabular}

$\mathrm{a}=(\mathrm{C} / \mathrm{T})$ and $\mathrm{R}=(\mathrm{A} / \mathrm{G})$

numbers KJ866102-KJ866147) identified in this study were deposited in the GenBank database.

\section{Results}

Sensitivity and specificity of semi-nested RT-PCR assays for coronavirus detection

Serial dilutions of coronavirus RNA transcripts (HCoV229E, HCoV-NL63, HCoV-OC43, HCoV-HKU1, and MERS-CoV) were tested using semi-nested RT-PCR. RNA transcripts for all virus types were detectable at $\leq 10$ copies per reaction, or $<400$ copies $/ \mathrm{mL}$ of sample. To evaluate detection specificity and possible cross-reactivity, nucleic acid from 18 different types of respiratory viruses were tested. All assay results were negative, and no false positive was observed.

\section{Prevalence of $\mathrm{HCoV}$ infection}

Among the 5833 samples analyzed, 637 (10.9\%) were positive for influenza A virus, 206 (3.5\%) were positive for influenza B virus, 201 (3.4\%) were positive for respiratory syncytial virus A, 91 (1.6\%) were positive for respiratory syncytial virus $B$, and 78 (1.3\%) were positive for adenovirus (Table 2). More importantly, 46 samples $(0.79 \%)$ tested positive for $\mathrm{HCoV}$. Co-infection with other respiratory viruses was not observed in the
Table 2 Identification of viruses in the samples obtained from $\mathbf{5 8 3 3}$ patients hospitalized for acute respiratory tract infection

\begin{tabular}{lc}
\hline Viruses & Number of samples tested positive (\%) \\
\hline HCoV-229E & $5(0.09)$ \\
HCoV-OC43 & $3(0.05)$ \\
HCoV-NL63 & $19(0.32)$ \\
HCoV-HKU1 & $19(0.32)$ \\
Influenza A virus & $637(10.9)$ \\
Influenza B virus & $206(3.5)$ \\
Adenovirus & $78(1.3)$ \\
Respiratory syncytial virus A & $201(3.4)$ \\
Respiratory syncytial virus B & $91(1.6)$ \\
\hline
\end{tabular}

$\mathrm{HCoV}$-positive samples. All samples were negative when tested for MERS-CoV $N$ gene.

Amongst the $\mathrm{HCoV}$-positive samples, $56.5 \%$ were from men and $43.5 \%$ were from women (gender ratio 1.3:1) (Table 3). $\mathrm{HCoV}$ infection was detected in all age groups, and the mean age of $\mathrm{HCoV}$-infected patients was 21.37 years $(\mathrm{min} .=4$ months, $\max .=93$ years, mean $=27.04$ years). The percentage of $\mathrm{HCoV}$ infection per year was $0.81 \%(23 / 2838)$ in 2012 and $0.77 \%$ 
Table 3 Demographic characteristics of individuals with respiratory tract infection

\begin{tabular}{|c|c|c|}
\hline \multirow[t]{2}{*}{ Characteristic } & \multicolumn{2}{|l|}{ Specimens } \\
\hline & No. specimens & Positive HCoV (\%) \\
\hline \multicolumn{3}{|l|}{ Gender } \\
\hline Male [n (\%)] & $2935(50.3)$ & $26(56.5)$ \\
\hline Female [n (\%)] & $2898(49.7)$ & $20(43.5)$ \\
\hline \multicolumn{3}{|l|}{ Age (years) } \\
\hline Median & 11 & 8.5 \\
\hline Mode & 1 & 1 \\
\hline Mean (SD) & $19.57(19.9)$ & $21.37(27.0)$ \\
\hline \multicolumn{3}{|l|}{ Age group } \\
\hline 0-5 [years (\%)] & $2197(37.7)$ & $25(54.3)$ \\
\hline 6-10 [years (\%)] & $732(12.5)$ & $2(4.3)$ \\
\hline 11-15 [years (\%)] & $538(9.2)$ & $6(13.0)$ \\
\hline 16-30 [years (\%)] & $866(14.8)$ & $3(6.5)$ \\
\hline 31-60 [years (\%)] & $1102(18.9)$ & $3(6.5)$ \\
\hline$>60$ [years (\%)] & $397(6.8)$ & $7(15.2)$ \\
\hline \multicolumn{3}{|l|}{ Provinces } \\
\hline Bangkok [n (\%)] & $3292(56.4)$ & $17(37.0)$ \\
\hline Khon Kaen [n (\%)] & 2408 (41.3) & $28(60.9)$ \\
\hline Chon Buri [n (\%)] & $132(2.3)$ & $1(2.2)$ \\
\hline
\end{tabular}

Numbers in parentheses indicate the percent of positive infection from total samples
(23/2995) in 2013. There were no seasonal peaks associated with $\mathrm{HCoV}$ and no positive samples were identified in the typically dry months of April and November during both years (Fig. 1).

The majority of $\mathrm{HCoV}(25 / 46$ or $54 \%)$ were detected mainly in young children between the ages of $0-5$ years and $15 \%$ in the elderly aged over 60 years (Fig. 2). Approximately $80 \%$ of the positive samples (37/46) were isolated from the NPS samples, while the rest $(9 / 46)$ were from the NPA samples. Furthermore, $46 \%$ (17/37) of all positive NPS and $89 \%(8 / 9)$ of all positive NPA samples belonged to the $0-5$ year age group.

To further differentiate the $46 \mathrm{HCoV}$-positive samples, the $S$ gene was sequenced. Analysis showed that these $\mathrm{HCoV}$ strains belonged to one of the four $\mathrm{HCoV}$ species (Table 2; Fig. 3). In all, 19 (0.32 \%) were positive for $\mathrm{HCoV}$ HKU1, 19 (0.32 \%) were positive for HCoV-NL63, 5 patients $(0.09 \%)$ were positive for $\mathrm{HCoV}-229 \mathrm{E}$, and $3(0.05 \%)$ were positive for $\mathrm{HCoV}-\mathrm{OC} 43$. Relative to all $\mathrm{HCoV}$-positive samples, therefore, the predominant genotypes were $41.3 \%$ for both HCoV-HKU1 and HCoV-NL63 (19/46), followed by $11 \% \mathrm{HCoV}-229 \mathrm{E}(5 / 46)$ and $6.5 \% \mathrm{HCoV}-\mathrm{OC} 43(3 / 46)$. Interestingly, $\mathrm{HCoV}-\mathrm{NL} 63$ and $\mathrm{HCoV}-\mathrm{HKU} 1$ appeared sporadically during the study period and were detected mainly in March 2012 and July 2013, respectively.

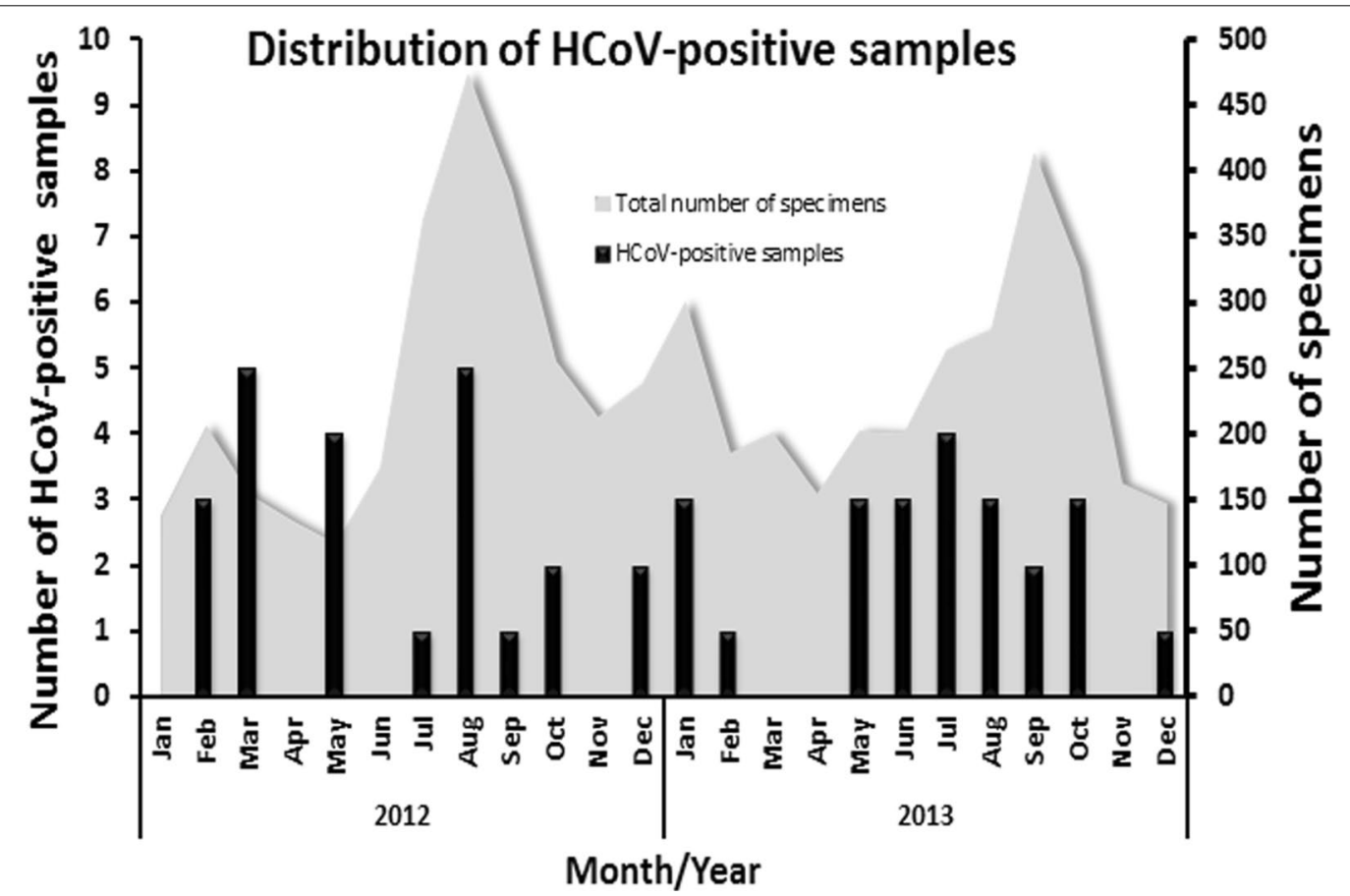

Fig. 1 Seasonal distribution of HCoV infection from January 2012 to December 2013. Gray area represents the total number of specimens from influenza-like illness each month (right scale). Bars represent the number of samples tested positive for HCoV (left scale) 


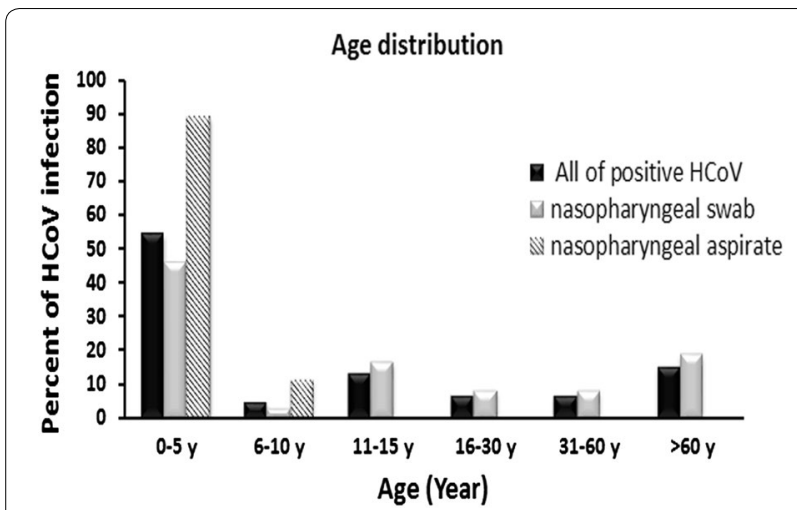

Fig. 2 Age distribution of HCoV infection. Percentage of HCoVpositive samples were derived from different age groups (black bars). Positive samples tested from nasopharyngeal swab and aspirate from each age group are indicated by gray and hatched bars, respectively

\section{Clinical characteristics of $\mathrm{HCoV}$ infections}

Of the $46 \mathrm{HCoV}$-positive samples, 38 (82.6\%) were derived from patients with acute infections involving the upper respiratory tract such as the nose, sinuses, pharynx or larynx (Table 4$)$. The remaining $8(17.4 \%)$ were from patients with lower respiratory tract infections. The most common clinical manifestations were fever and rhinorrhea, although several patients experienced tachypnea and hypoxemia.

\section{Molecular characterization of different HCoVs}

To assess the relationship among the strains identified, partial nucleotide sequences of the $S$ gene from $\mathrm{HCoV}$ positive samples were subjected to phylogenetic analysis (Fig. 4). This region was examined as it represents the antigenic determinant of the virus and correlates with strain evolution. HCoV-HKU1 strains identified in this study formed a single cluster ( $99.6 \%$ sequence identity) within clade $B$ together with the strain identified on mainland China. Meanwhile, HCoV-NL63 strains clustered in two different groups within the same clade. Their sequences were genetically closest to the isolates from The Netherlands and U.S.A. Three HCoV-OC43 strains grouped together with previous viruses characterized in Japan in clade C. Finally, although the $5 \mathrm{HCoV}-229 \mathrm{E}$ identified in this study appeared to cluster into a new group, they demonstrated nearest genetic resemblance to strains from Japan and China.

\section{Discussion}

Due to the awareness of MERS-CoV and other novel human coronavirus infections worldwide, this study aimed to characterize possible circulation and prevalence of $\mathrm{HCoV}$ in Thailand in a 2-year period. The $\mathrm{HCoV}$ prevalence of $0.79 \%$ found in this study was lower than that from previous reports, which ranged from 2.1 to 5.7 \% (Bellei et al. 2008; Dominguez et al. 2009; Gorse

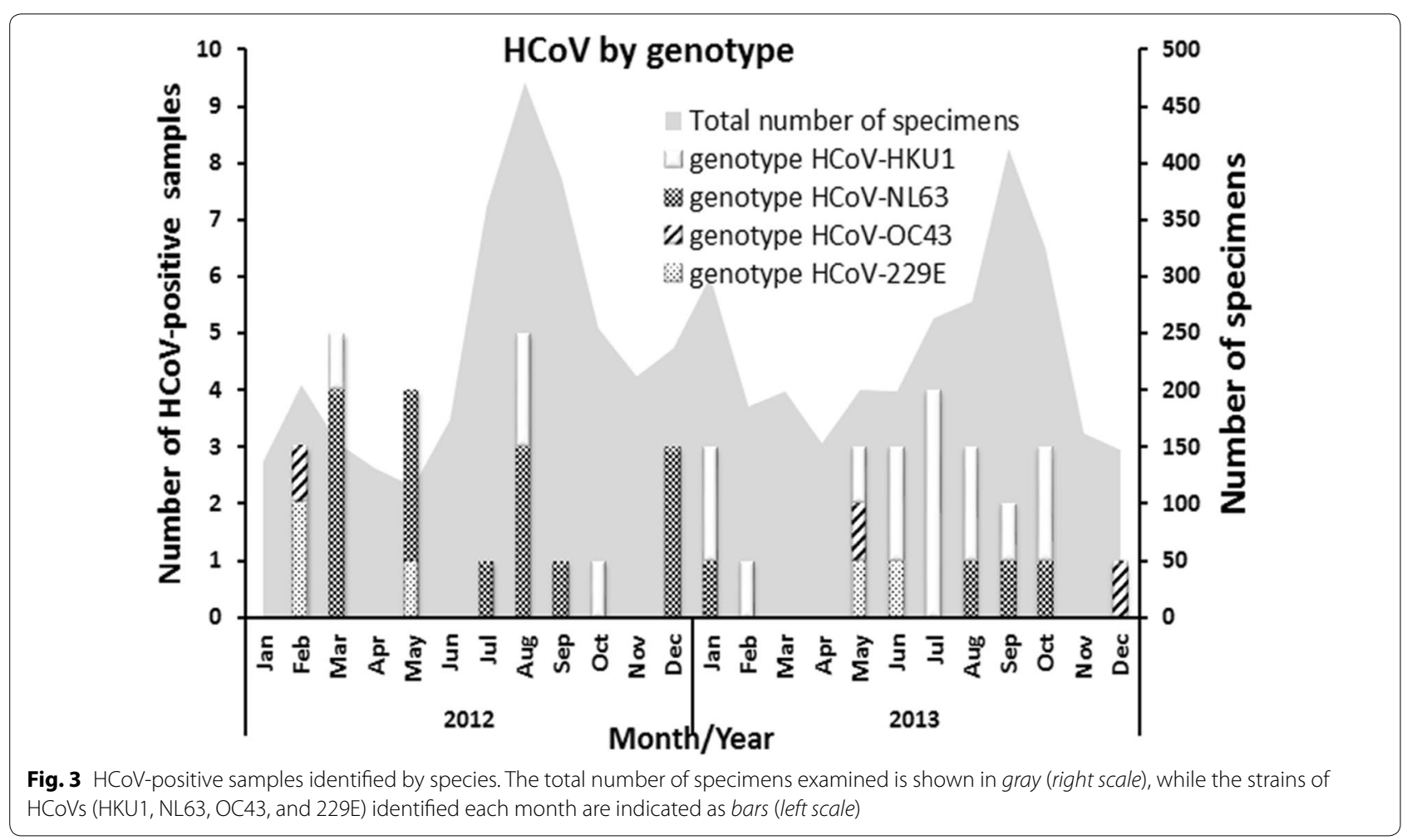


Table 4 Clinical characteristics of patients with HCoV infection

\begin{tabular}{|c|c|c|c|c|}
\hline \multirow[t]{2}{*}{ Characteristic } & \multicolumn{4}{|c|}{ HCoV-positive individuals (\%) } \\
\hline & HCoV-229E & HCoV-OC43 & HCoV-NL63 & HCoV-HKU1 \\
\hline $\begin{array}{c}\text { Total no. of } \\
\text { patients }\end{array}$ & 5 & 3 & 19 & 19 \\
\hline URTI & 5 & 2 & $16(84 \%)$ & $15(79 \%)$ \\
\hline LRTI & 0 & 1 & $3(16 \%)$ & 4 (21\%) \\
\hline \multicolumn{5}{|c|}{ Clinical symptom } \\
\hline Fever & 5 & 3 & 18 (95\%) & $16(84 \%)$ \\
\hline Cough & 2 & 2 & $11(58 \%)$ & $10(53 \%)$ \\
\hline Sputum & 0 & 1 & $5(26 \%)$ & $2(11 \%)$ \\
\hline Rhinorrhea & 4 & 2 & $16(84 \%)$ & 17 (89 \%) \\
\hline Vomiting & 3 & 0 & $10(53 \%)$ & $12(63 \%)$ \\
\hline Tachypneab $^{\text {b }}$ & 0 & 1 & $6(32 \%)$ & $7(37 \%)$ \\
\hline Hypoxemiac $^{c}$ & 1 & 1 & $5(26 \%)$ & $5(26 \%)$ \\
\hline $\begin{array}{l}\text { Respiratory } \\
\text { distress }^{\mathrm{d}}\end{array}$ & 0 & 1 & $6(32 \%)$ & $7(37 \%)$ \\
\hline $\begin{array}{l}\text { Abnormal } \\
\text { breathing } \\
\text { sound }\end{array}$ & 0 & 1 & 6 (32 \%) & 7 (37 \%) \\
\hline
\end{tabular}

URT/ upper respiratory tract infection, $L R T /$ lower respiratory tract infection (pneumonia, bronchiolitis, and acute infection of the pulmonary parenchyma)

a Percent of HCoV-positive individuals with such symptoms

${ }^{b}$ Age-related definition of tachypnea by The World Health Organization for individuals $<2$ months ( $>60$ breaths $/ \mathrm{min}$ ), $2-12$ months ( $>50$ breaths $/ \mathrm{min}$ ), $1-5$ years ( $>40$ breaths $/ \mathrm{min}$ ) and $>5$ years ( $>20$ breaths $/ \mathrm{min}$ )

c Oxygen saturation (SpO2) level below $95 \%$

d Including retractions (subcostal, intercostal, suprasternal), nasal flaring, and grunting

e Crepitation, rhonchi, and wheezing

et al. 2009; Pierangeli et al. 2007). However, the rate of $\mathrm{HCoV}$-positive samples found in this study was similar to the level of infection reported in countries such as mainland China (1\%) (Ren et al. 2011) and United Kingdom $(0.85 \%)$ (Gaunt et al. 2010). Several factors may account for this disparity: (1) the subjects included in this study were adult patients whereas other studies examined mainly hospitalized children (Talbot et al. 2009) or adults with underlying diseases (Dare et al. 2007), (2) the viral infection rate obtained from NPS used in this study may be lower than that of NPA (Lau et al. 2006; Talbot et al. 2009), (3) differences in the study time frame and geographical area, (4) natural varying of yearly distribution of $\mathrm{HCoV}$ species, and (5) differences in the techniques used for testing, such as conventional versus real-time PCR.

Although a previous study in southern Thailand found that $\mathrm{HCoV}-\mathrm{OC} 43$ was the predominant strain (Suwannakarn et al. 2014), very few $\mathrm{HCoV}-\mathrm{OC} 43$ infections were detected in this study. Yearly fluctuation in the predominance of $\mathrm{HCoV}$ strains in Thailand has been documented (Dare et al. 2007). The majority of $\mathrm{HCoVs}$ detected in this study was $\mathrm{HCoV}-\mathrm{NL} 63$ and $\mathrm{HCoV}$ HKU1. HCoV-NL63 was found mainly in 2012 and $\mathrm{HCoV}-\mathrm{HKU} 1$ in 2013, while $\mathrm{HCoV}-\mathrm{OC} 43$ and $\mathrm{HCoV}-$ $229 \mathrm{E}$ were sporadic and less frequent.

$\mathrm{HCoV}$ infections elicited common symptoms such as fever, cough, headache, vomiting, muscle pain and sore throat. Upper respiratory tract infection such as rhinorrhea, sputum, and lower respiratory tract infection such as tachypnea and abnormal breath sounds were frequently observed in our patients similar to past observations (Ren et al. 2011; Dominguez et al. 2009). However, clinical presentations were slightly different among each subtype of $\mathrm{HCoV}$. In this study, vomiting was more common in $\mathrm{HCoV}-229 \mathrm{E}, \mathrm{HCoV}-\mathrm{NL} 63$ and $\mathrm{HCoV}-\mathrm{HKU} 1$-positive patients but not in those infected by $\mathrm{HCoV}-\mathrm{OC} 43$. Lower respiratory tract infections were associated with individuals with $\mathrm{HCoV}$ OC43, HCoV-NL63, and HCoV-HKU1, but not in those with HCoV-229E. Tachypnea, hypoxemia, abnormal breathing sound and signs of respiratory distress also occurred less often for $\mathrm{HCoV}-229 \mathrm{E}$. These clinical features were very similar to those observed with other respiratory viruses, such as RSV, HPIV, and human metapneumovirus.

The simultaneous screening for common respiratory viruses allowed us to investigate possible co-infection of $\mathrm{HCoV}$ with other viral pathogens. Although parainfluenza viruses, enteroviruses, and human metapneumovirus were not tested, co-infection of $\mathrm{HCoV}$ with RSV was never observed (Theamboonlers et al. 2007). It may be that $\mathrm{HCoV}$ and other respiratory viruses do not share the same seasonal circulation. The possibility of viral coinfection with bacteria, however, cannot be ruled out. Nevertheless, confirmation of the mechanism of co-infection will require good clinical sampling and further longitudinal studies conducted over several years.

Previous characterization of the genetic variation and evolution of $\mathrm{HCoV}$ have utilized the whole viral genome, $S, R d R p$, or $N$ gene. Here, the phylogenetic analysis of $\mathrm{HCoV}$ was performed based on the sequences of partial spike gene because the $S$ gene may be more discriminating than the $R d R p$ gene (Lau et al. 2006, 2011). While phylogenetic grouping of HCoVHKU1, HCoV-NL63, and HCoV-OC43 were characterized by clades or clusters, $\mathrm{HCoV}-229 \mathrm{E}$ strains were typically subdivided by the year of emergence. $\mathrm{HCoV}$ $229 \mathrm{E}$ strains collectively appeared to form a new cluster similar to but distinct from previous strains in the phylogenetic tree. 


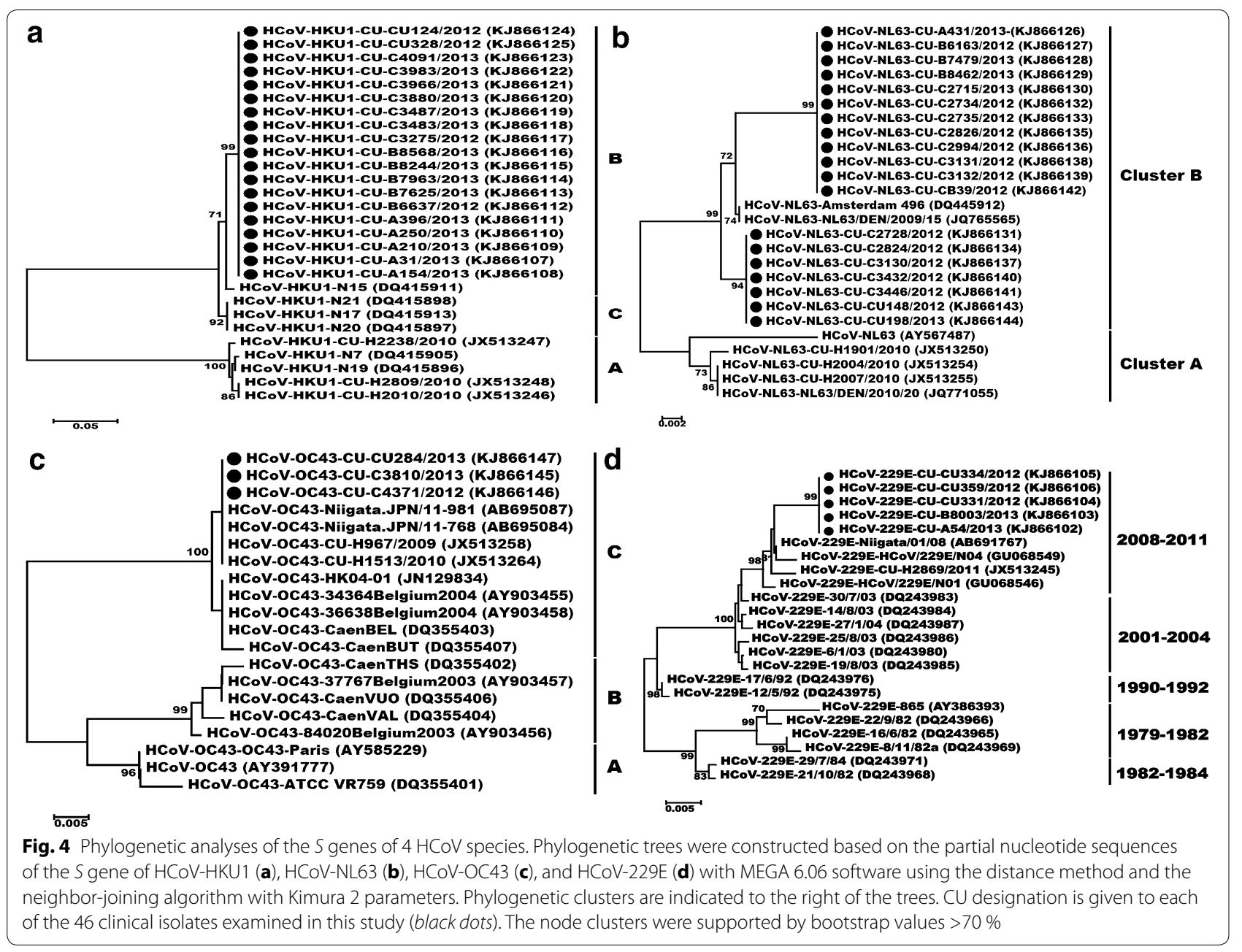

\section{Conclusions}

In summary, this study surveyed the prevalence and clinical presentations of different $\mathrm{HCoV}$ infections in Thai patients from 2012 to 2013. Although the numbers of $\mathrm{HCoV}$-positive samples were low, we detected four species of $\mathrm{HCoV}$ and phylogenetically characterized their diversity. These viruses appeared to continue to cause infections globally, thus accurate and timely diagnosis will be essential. The assay described in this study can be used to assist in the rapid and accurate detection of emerging $\mathrm{HCoV}$ infection.

\section{Abbreviations}

HCoV: human coronavirus; NPA: nasopharyngeal aspirate; NPS: nasopharyngeal swab; RSV: respiratory syncytial virus; RT-PCR: reverse-transcription polymerase chain reaction.

\section{Authors' contributions}

RS, IT and PV performed the experiments. SP and YP designed the research study. CV and VV collected the samples. RS, SV, and YP wrote the manuscript. All authors read and approved the final manuscript.
Author details

${ }_{1}^{1}$ Department of Biochemistry, Faculty of Medicine, Chulalongkorn University, Bangkok, Thailand. ${ }^{2}$ Center of Excellence in Clinical Virology, Department of Pediatrics, Faculty of Medicine, Chulalongkorn University, Bangkok, Thailand. ${ }^{3}$ Chum Phae Hospital, Khon Kaen, Thailand.

\section{Competing interests}

The authors declare that they have no competing interests.

Availability of data and materials

The dataset supporting the conclusions of this article is available within this manuscript.

Ethics approval and consent

This study was approved by the Faculty of Medicine, Chulalongkorn University (IRB 388/56).

\section{Funding}

This work was supported by the Bureau of General Communicable Disease, Department of Disease Control (DDC), Ministry of Public Health; The National Research Council of Thailand (NRCT); the Thailand Research Fund (TRF: RSA5680031); The Research Chair Grant from the National Science and Technology Development Agency; Chulalongkorn University Centenary Academic Development Project (CU56-HR01); Ratchadaphiseksomphot Endowment Fund of Chulalongkorn University (RES560530093); The Outstanding Professor of Thailand Research Fund (DPG5480002); and The Center of Excellence in 
Clinical Virology of Chulalongkorn University (GCE 58-014-30-004); King Chulalongkorn Memorial Hospital; the 100th Anniversary Chulalongkorn University Fund for doctoral scholarship awarded to llada Thongpan; The National Blood Center, Thai Red Cross; MK Restaurant Company; and The Siam Cement Group.

Received: 12 May 2016 Accepted: 18 August 2016

Published online: 26 August 2016

\section{References}

Auksornkitti V, Kamprasert N, Thongkomplew S, Suwannakarn K, Theamboonlers A, Samransamruajkij R, Poovorawan Y (2014) Molecular characterization of human respiratory syncytial virus, 2010-2011: identification of genotype ON1 and a new subgroup B genotype in Thailand. Arch Virol 159(3):499-507

Bellei N, Carraro E, Perosa A, Watanabe A, Arruda E, Granato C (2008) Acute respiratory infection and influenza-like illness viral etiologies in Brazilian adults. J Med Virol 80(10):1824-1827

Corman VM, Muller MA, Costabel U, Timm J, Binger T, Meyer B, Kreher P, Lattwein E, Eschbach-Bludau M, Nitsche A, Bleicker T, Landt O, Schweiger B, Drexler JF, Osterhaus AD, Haagmans BL, Dittmer U, Bonin F, WolffT, Drosten C (2012) Assays for laboratory confirmation of novel human coronavirus (hCoV-EMC) infections. Euro Surveill 17(49):20334

Dare RK, Fry AM, Chittaganpitch M, Sawanpanyalert P, Olsen SJ, Erdman DD (2007) Human coronavirus infections in rural Thailand: a comprehensive study using real-time reverse-transcription polymerase chain reaction assays. J Infect Dis 196(9):1321-1328

Dominguez SR, Robinson CC, Holmes KV (2009) Detection of four human coronaviruses in respiratory infections in children: a one-year study in Colorado. J Med Virol 81(9):1597-1604

Drosten C, Gunther S, Preiser W, van der Werf S, Brodt HR, Becker S, Rabenau H, Panning M, Kolesnikova L, Fouchier RA, Berger A, Burguiere AM, Cinatl J, Eickmann M, Escriou N, Grywna K, Kramme S, Manuguerra JC, Muller S, Rickerts V, Sturmer M, Vieth S, Klenk HD, Osterhaus AD, Schmitz H, Doerr HW (2003) Identification of a novel coronavirus in patients with severe acute respiratory syndrome. N Engl J Med 348(20):1967-1976

Gaunt ER, Hardie A, Claas EC, Simmonds P, Templeton KE (2010) Epidemiology and clinical presentations of the four human coronaviruses 229E, HKU1, NL63, and OC43 detected over 3 years using a novel multiplex real-time PCR method. J Clin Microbiol 48(8):2940-2947

Gonzalez JM, Gomez-Puertas P, Cavanagh D, Gorbalenya AE, Enjuanes L (2003) A comparative sequence analysis to revise the current taxonomy of the family Coronaviridae. Arch Virol 148(11):2207-2235

Gorse GJ, O'Connor TZ, Hall SL, Vitale JN, Nichol KL (2009) Human coronavirus and acute respiratory illness in older adults with chronic obstructive pulmonary disease. J Infect Dis 199(6):847-857

Hilgenfeld R, Peiris M (2013) From SARS to MERS: 10 years of research on highly pathogenic human coronaviruses. Antivir Res 100(1):286-295

Kon M, Watanabe K, Tazawa T, Watanabe K, Tamura T, Tsukagoshi H, Noda M, Kimura H, Mizuta K (2012) Detection of human coronavirus NL63 and OC43 in children with acute respiratory infections in Niigata, Japan, between 2010 and 2011. Jpn J Infect Dis 65(3):270-272

Lai MM, Cavanagh D (1997) The molecular biology of coronaviruses. Adv Virus Res 48:1-100

Lau SK, Woo PC, Yip CC, Tse H, Tsoi HW, Cheng VC, Lee P, Tang BS, Cheung CH, Lee RA, So LY, Lau YL, Chan KH, Yuen KY (2006) Coronavirus HKU1 and other coronavirus infections in Hong Kong. J Clin Microbiol 44(6):2063-2071

Lau SK, Lee P, Tsang AK, Yip CC, Tse H, Lee RA, So LY, Lau YL, Chan KH, Woo PC, Yuen KY (2011) Molecular epidemiology of human coronavirus
OC43 reveals evolution of different genotypes over time and recent emergence of a novel genotype due to natural recombination. J Virol 85(21):11325-11337

Lu R, Yu X, Wang W, Duan X, Zhang L, Zhou W, Xu J, Xu L, Hu Q, Lu J, Ruan L, Wang Z, Tan W (2012) Characterization of human coronavirus etiology in Chinese adults with acute upper respiratory tract infection by real-time RT-PCR assays. PLoS ONE 7(6):e38638

McIntosh K, Chao RK, Krause HE, Wasil R, Mocega HE, Mufson MA (1974) Coronavirus infection in acute lower respiratory tract disease of infants. J Infect Dis 130(5):502-507

Memish ZA, Zumla Al, Al-Hakeem RF, Al-Rabeeah AA, Stephens GM (2013) Family cluster of Middle East respiratory syndrome coronavirus infections. N Engl J Med 368:2487-2494

Moës E, Vijgen L, Keyaerts E, Zlateva K, Li S, Maes P, Pyrc K, Berkhout B, van der Hoek L, Van Ranst M (2005) A novel pancoronavirus RT-PCR assay: frequent detection of human coronavirus NL63 in children hospitalized with respiratory tract infections in Belgium. BMC Infect Dis 5:6

Pierangeli A, Gentile M, Di Marco P, Pagnotti P, Scagnolari C, Trombetti S, Lo Russo L, Tromba V, Moretti C, Midulla F, Antonelli G (2007) Detection and typing by molecular techniques of respiratory viruses in children hospitalized for acute respiratory infection in Rome, Italy. J Med Virol 79(4):463-468

Prachayangprecha S, Makkoch J, Suwannakarn K, Vichaiwattana P, Korkong S, Theamboonlers A, Poovorawan Y (2013) Epidemiology of seasonal influenza in Bangkok between 2009 and 2012. J Infect Dev Ctries 7(10):734-740

Ren L, Gonzalez R, Xu J, Xiao Y, Li Y, Zhou H, Li J, Yang Q, Zhang J, Chen L, Wang W, Vernet G, Paranhos-Baccala G, Wang Z, Wang J (2011) Prevalence of human coronaviruses in adults with acute respiratory tract infections in Beijing, China. J Med Virol 83(2):291-297

Rota PA, Oberste MS, Monroe SS, Nix WA, Campagnoli R, Icenogle JP, Penaranda S, Bankamp B, Maher K, Chen MH, Tong S, Tamin A, Lowe L, Frace M, DeRisi JL, Chen Q, Wang D, Erdman DD, Peret TC, Burns C, Ksiazek TG, Rollin PE, Sanchez A, Liffick S, Holloway B, Limor J, McCaustland K, Olsen-Rasmussen M, Fouchier R, Gunther S, Osterhaus AD, Drosten C, Pallansch MA, Anderson LJ, Bellini WJ (2003) Characterization of a novel coronavirus associated with severe acute respiratory syndrome. Science 300(5624):1394-1399

Sriwanna P, Chieochansin T, Vuthitanachot C, Vuthitanachot V, Theamboonlers A, Poovorawan Y (2013) Molecular characterization of human adenovirus infection in Thailand, 2009-2012. Virol J 10:193

Suwannakarn K, Chieochansin T, Vichiwattana P, Korkong S, Theamboonlers A, Poovorawan Y (2014) Prevalence and genetic characterization of human coronaviruses in southern Thailand from July 2009 to January 2011. Southeast Asian J Trop Med Public Health 45:326-336

Talbot HK, Crowe JE Jr, Edwards KM, Griffin MR, Zhu Y, Weinberg GA, Szilagyi PG, Hall CB, Podsiad AB, Iwane M, Williams JV, Network NVS (2009) Coronavirus infection and hospitalizations for acute respiratory illness in young children. J Med Virol 81(5):853-856

Theamboonlers A, Samransamruajkit R, Thongme C, Amonsin A, Chongsrisawat V, Poovorawan Y (2007) Human coronavirus infection among children with acute lower respiratory tract infection in Thailand. Intervirology 50(2):71-77

van Elden $L$, van Loon AM, van Alphen F, Hendriksen KA, Hoepelman Al, van Kraaij MG, Oosterheert JJ, Schipper P, Schuurman R, Nijhuis M (2004) Frequent detection of human coronaviruses in clinical specimens from patients with respiratory tract infection by use of a novel real-time reverse-transcriptase polymerase chain reaction. J Infect Dis 189:652-657

Zaki AM, van Boheemen S, Bestebroer TM, Osterhaus AD, Fouchier RA (2012) Isolation of a novel coronavirus from a man with pneumonia in Saudi Arabia. N Engl J Med 367(19):1814-1820 